\title{
TYÖLLISYYDEN MUUTOS JA KOULUTUKSEN MERKITYS
}

\author{
Asko Suikkanen \& Ritva Linnakangas \& Sirpa Martti
}

Korkeasti koulutettujen työmarkkina-asema on aina ollut vahvempi kuin alhaisemman koulutuksen omaavien. 1990-luvulta alkaen palkkatyöhön osallistuminen ja työttömyysriski ovat kuitenkin entistä voimakkaammin alkaneet eriytyä koulutuksen mukaan. Kohtalaisen hyvän työmarkkina-aseman saavuttaminen edellyttää jo vähintään ylemmän keskiasteen tutkinnon suorittamista, jatkuvaa valmiutta kouluttautua sekä elinikäisen oppimisen periaatteen sisäistämistä.

Rakenteelliseksi muuttunut työttömyys, epävakaa työllisyys, työttömyyskokemusten yleistyminen ja heikosti koulutettujen kasvanut riski pitkittyvään työttömyyteen merkitsevät sitä, että täystyöllisyyden perustalle rakentuva hyvinvointivaltio ja sen korjaava politiikka ovat käyneet riittämättömiksi. Uudessa tilanteessa tarvitaan painopisteen siirtämistä aktivoivaan, uusia mahdollisuuksia avaavaan politiikkaan. Aikuiskoulutuksessa tämä merkitsee sitä, että epävakaan työllisyyden oloissa aikuisten mahdollisuuksia lähteä opiskelemaan tulee tukea.

Käsillä oleva artikkeli pohjautuu empiiriseen tutkimukseen (Suikkanen ym. 2002), jossa tutkimuksen kohteena oli koulutuksen merkityksen muuttuminen työmarkkinoilla pärjäämisen edellytyksenä. Siinä, että pidemmälle koulutettujen asema työmarkkinoilla on ollut yleisesti ottaen parempi kuin vähän koulutusta saaneiden, ei sinällään ole mitään uutta. Uutta sen sijaan on se, että työmarkkina-asemat ovat entistä voimakkaammin alkaneet eriytyä koulutustason mukaan.
Uutta on myös se, että enää edes korkea-asteen koulutus ei takaa vakaata työmarkkina-asemaa eikä normaalia työsuhdetta. Työmarkkinoilla tapahtuneiden muutosten taustalla on monia tekijöitä kuten talouden globalisoituminen, tietoyhteiskuntakehitys, uuden tekniikan käyttöön otto, työn tekemisen tapojen muuttuminen, projektiluonteisen työn yleistyminen ja niin yritysten kuin työsuhteidenkin pilkkoutuminen sekä tuotantorakenteessa tapahtuneet muutokset, joiden myötä vähäistä koulutusta vaativat työtehtävät ja alat ovat vähentyneet merkittävästi. Muutosta leimaavat työelämän kasvavat vaatimukset ja työvoiman sisäisen kilpailun kiristyminen.

Kuvaamme artikkelissa työllisyyden kehitystrendejä, palkkatyöhön osallistumista ja työttömyyden laajuutta koulutusasteen mukaan. Tuloksemme ovat samansuuntaisia kuin aikaisemmissakin tutkimuksissa, joissa on tutkittu koulutustason ja työttömyyden välistä yhteyttä (esim. Vähätalo 1998; Silvennoinen 1999). Tutkimuksen erityisenä vahvuutena pidämme aineiston laajuut- 
ta sekä lähes koko 1990-luvun kattavaa pitkittäisanalyysia. Tutkimusaineisto pohjautuu Tilastokeskuksen muodostamaan yksilökohtaiseen rekisteriaineistoon koko työikäisestä väestöstä (5 \%:n otokseen perustuen) vuosilta 1988-1998. Ero aiempiin tutkimuksiin on siinä, että kuvaamme eri koulutusasteita suorittaneiden työttömyyden eriytymistä käyttämällä vuosityöttömyysaste-mittaria. Vuosityöttömyysaste (käsite: Suikkanen 1998 ja 2001) kertoo, toisin kuin poikkileikkaustieto, kuinka suuri osa työvoimaan kuuluvista on vuoden aikana ollut työttömänä joko kerran tai useampia kertoja. Sen käyttäminen antaa työttömyyden merkittävyydestä varsin kokonaisvaltaisen kuvan ja koulutusasteen mukaan tarkasteltuna sen avulla on mahdollista kuvata työttömyyden esiintymistiheyttä työvoiman eri koulutustasoryhmissä. Työllisyyden ja koulutuksen välistä suhdetta kuvaavat tulokset puolestaan vahvistavat saatuja tuloksia koulutustason yhteydestä työsuhteen laatuun (esim. Sutela ym. 2001). Tulokset voivat vaikuttaa itsestään selviltä, mutta eivät sitä ole. Kuvaamme vuositasolla koko vuoden kestäneen palkkatyön ja koulutusasteen välistä yhteyttä palkkatyövoimassa. Palkkatyövoimaksi olemme määritelleet sen osan työvoimaa, johon yrittäjät eivät lukeudu mukaan. Näkökulma muodostuu tällöin toiseksi kuin jos tarkastellaan yksinomaan palkansaajien joukkoa. Saadaan tietoa siitä, kuinka suuri osa (tietyn koulutusasteen suorittaneesta) työvoimasta (yrittäjät pois lukien) on kokovuotisessa palkkatyössä. Näin tarkastellen saadaan esiin epävakaan työllisyyden laajuus ja sen yhteys koulutustasoon varsin hyvin.

\section{TYÖLLISYYDEN MUUTOKSEN TULKINTA}

Tyypillinen, eli niin sanottu normaalityösuhde, on perinteisesti ollut kokoaikainen, säännöllinen ja rajoittamaton. Hyvinvointiyhteiskunnassa se on ollut keskeinen taloudellisen ja sosiaalisen selviytymisen mahdollistaja yksilöiden eri elämänvaiheissa ja riskitilanteissa. Normaalityösuhteen sosiaaliset oikeudet ovat olleet sidotut yksilöiden työhistoriaan. Sosiaalivakuutuksen tuottamien etujen taso on määräytynyt työsuhteen keston ja ansioiden mukaan. Pitkä työsuh-

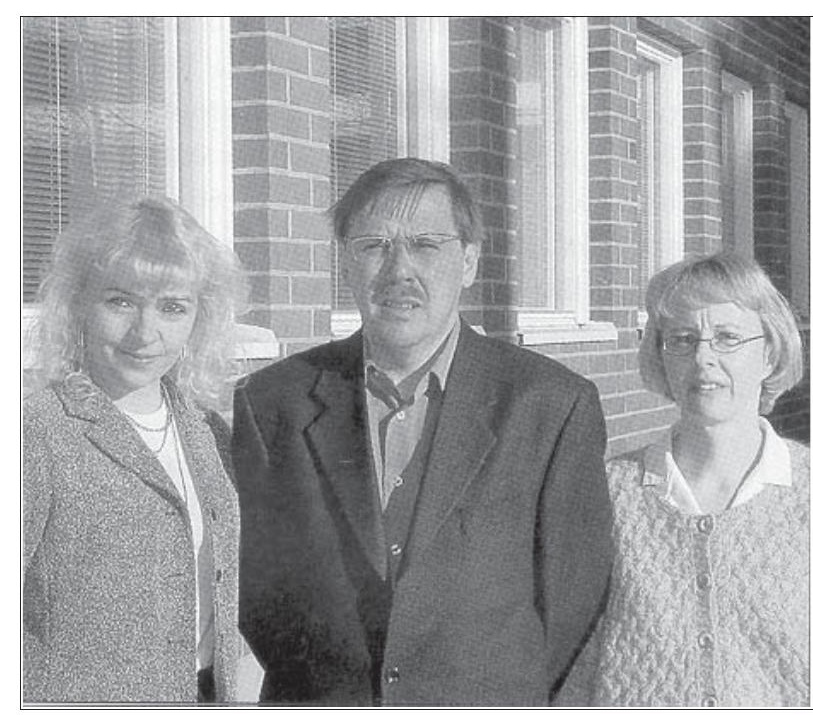

Lapin yliopiston tutkijaryhmä: Sirpa Martti, Asko Suikkanen ja Ritva Linnakangas

de ja työhistoria ovat taanneet taloudellisen selviytymisen ja suojanneet yksilöä erilaisilta riskeiltä. Ne ovat merkinneet keskimääräistä parempia mahdollisuuksia työmarkkinoilla ja yksilötasolla niihin on liittynyt odotus jatkuvasta hyvinvoinnin kasvusta. (Koistinen 1986; Linnakangas 1997; Suikkanen ym. 1999.)

Työllisyyden epävakaistumisesta, normaalin palkkatyön määrän vähenemisestä ja näiden muutosten pysyvyydestä on keskusteltu vilkkaasti 1990-luvulla. Joidenkin näkemysten mukaan paluuta täystyöllisyyteen pidetään mahdollisena ja tavoiteltavana (Ilmakunnas ym. 2000) tai ei ainakaan uskota epävakaan työllisyyden lisääntymiseen yhteiskunnassa (World Employment Report 2001; Tietoyhteiskunta-asiain neuvottelukunta... 2001). Työmarkkinoiden supistumista korostavien käsitysten mukaan vajaatyöllisyyden tila on puolestaan pysyvä ja yhteiskunta on siirtymässä vaiheeseen, jossa ei ole paluuta täystyöllisyyteen. Näkökulmasta riippuen tämän kehityksen oletetaan tapahtuvan eri tavoin. On puhuttu ainakin "hauraasta" (Beck 1999) ja "uudesta" (Schmid 1998) täystyöllisyydestä, joilla viitataan perinteisen täystyöllisyyden väistymiseen.

Schmid määrittelee nykyiset työmarkkinat siir- 
tymien työmarkkinoiksi. Lähtökohtana on ajatus, että yhä useamman kohdalla katkokselliset työurat leimaavat työhön osallistumista. Myös Beckin mukaan Euroopassa ollaan siirtymässä vähitellen pysyvään vajaatyöllisyyteen. Hän tulkitsee työmarkkinoiden muutoksen ja yksilöllistymisen liittyvän modernisaatiokehitykseen, jossa tapahtuu vähittäinen siirtymä ensimmäisestä modernista toiseen moderniin. Ensimmäisellä modernilla viitataan teollisuusyhteiskuntaan, jossa tuotanto ja talous perustuivat teollisuuteen, työmarkkinat toimivat yksilöiden sosiaalisten päämäärien luojina, valtiokeskeisyys korostui, sosiaalinen integraatio toteutui kansalaisuuden kautta ja sosiaalinen järjestys perustui neuvotteluihin. (Ks. Beck 1990, 1995, 2000; Giddens 1990, 1995; Heiskala 1998.) Ensimmäiseen moderniin liittyivät läheisesti kollektiiviset elämäntavat ja täystyöllisyys, ja työmarkkinat olivat verrattain vakaat. Työsuhteet olivat tavallisesti koko työuran kestäviä ja kokoaikaisia. Yksilöt kiinnittyivät pysyvästi työmarkkinoille ja työelämään sinne kerran siirryttyään. Erilaiset siirtymät, kuten työllisestä työttömäksi tai työllisestä opiskelijaksi, olivat työuran aikana verraten harvinaisia. Kerran hankittu koulutus ja ammatti riittivät koko työuran ajaksi. Työttömyys oli lähinnä suhdannetyöttömyyttä ja tästä johtuen laajamittainenkin työttömyys oli verraten nopeasti ohimenevä ilmiö. Noususuhdanteen aikana heikosti koulutetut ja koulutusta vailla olevatkin onnistuivat työllistymään.

Siirryttäessä toiseen moderniin ensimmäiseen moderniin liittyvät teollisen yhteiskunnan olennaiset peruspiirteet alkavat murtua. Valtiokeskeisyys heikkenee. Uudet tuotantomuodot ja niiden periaatteet alkavat osaltaan korvata teollisuutta. Perinteiset talouden toimintamuodot ja säännönmukaisuudet muuttuvat uudessa toimintaympäristössä. Yksilöitymiskehitys ja erilaistuminen nousevat kollektiivisten arvojen ja päämäärien rinnalle. Työmarkkinoilla tapahtuu eriytymistä, mikä merkitsee yksilötasolla epävarmuutta, yksilöllistettyjä riskejä ja työurien epäjatkuvuutta ja eriytymistä. Muutoksen kiihdyttäjänä toimivat mm. koulutus, kiristyvä kilpailu ja liikkuvuuden lisääntyminen, jotka vahvistavat toinen toistaan. Yksilöt joutuvat kohtaamaan ja ko- kemaan yksilöllisesti riskit, jotka kohdattiin ja joita pyrittiin hallitsemaan aikaisemmin kollektiivisesti ja hyvinvointivaltion puitteissa.

Koulutuksen hankkimisesta on muodostunut aikaisempaa keskeisempi keino tai pyrkimys hallita työmarkkina-asemaan liittyvää epävarmuutta. Koulutustason nostaminen, uuden ammatin hankkiminen, usean tutkinnon suorittaminen sekä jatkuva itsensä kehittäminen ja opiskelu ovat muodostumassa työmarkkinoilla selviytymisen ehdoiksi. Epävarmuuden keskellä pitkien yhtenevien elämänjaksojen katkokset ja elämänvaiheiden siirtymät ja nopeatkin vaihtumiset yleistyvät. Työmarkkina-asemavaihdokset eivät ole enää "heikkoja signaaleja" tai ainoastaan työuran alkuun liittyviä tilanteita. Ne ovat yleistyneet varsinkin nuorilla ikäluokilla ja naisilla. Työmarkkinoiden kasvavat vaatimukset ja työvoiman sisäisen kilpailun kiristyminen pakottavat yksilöt järjestämään arkensa ja elämänkulkunsa uudella tavalla.

\section{TYÖLLISYYDENJATYÖTTÖMYYDEN ERIYTYMINEN KOULUTUSASTEEN MUKAAN}

Tuotantorakenteen muutokset, koulutuksen merkityksen kasvu ja työelämän kiristyneet koulutustasovaatimukset näkyvät niin harjoitetussa koulutuspolitiikassa kuin myös muutoksina työllisen ja työttömän työvoiman koulutusrakenteessa. Tuotannon rakenteessa tapahtuneisiin muutoksiin on koulutuspolitiikassa vastattu keskittymällä pääsääntöisesti nuorten koulutuksen kehittämiseen, minkä seurauksena Suomelle leimallinen ero nuorten ja vanhempien ikäluokkien koulutustasossa on pysynyt suurena. Jos koulutustasonormina ymmärretään raja, joka jakaa työllisen työvoiman kahteen yhtä suureen osaan (50 \% ja 50 \%), 1990-luvun lopussa pelkkä perusasteen koulutus oli normina 60 vuotta täyttäneillä ja lähinnä alemman keskiasteen koulutus 35-59vuotiailla työllisillä. Ainoastaan alle 35-vuotiailla työllisillä normina on vähintään ylempi keskiaste, mikä riittää vastaamaan uusiin työsuhteisiin rekrytoivien yritysten ja teollisuuden vaatimuksia (vrt. TT:n koulutuspoliittiset teesit). (Kuvio 1.) 
Kuvio 1. Työllisen työvoiman koulutusrakenne iän mukaan vuonna 1998.

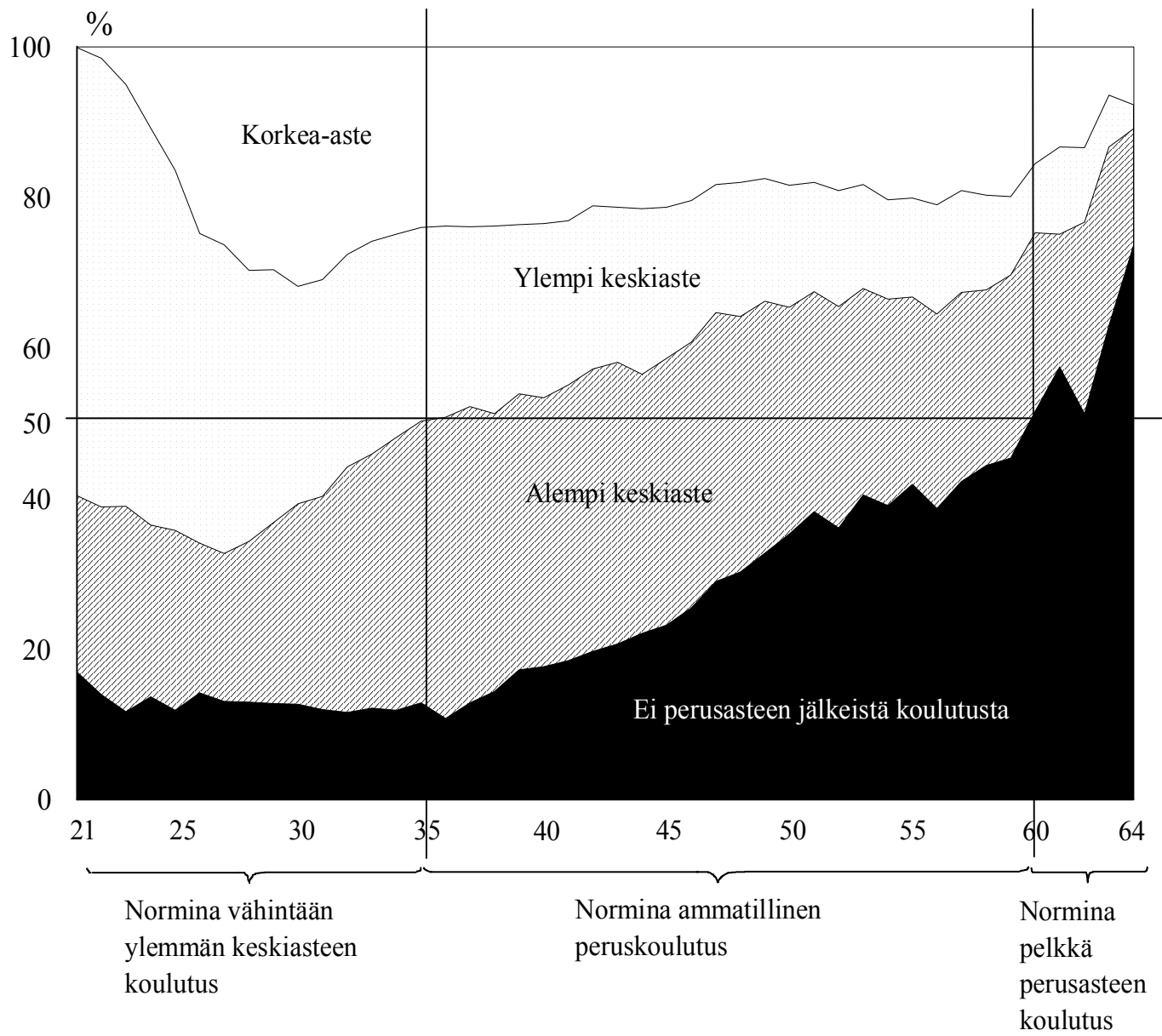

Vajaassa kymmenessä vuodessa vähän koulutusta den osuus on muodostumassa yli puoleksi työlliseen työvoimaan kuuluvista. 1990-luvun lopussa kaikista suomalaisista työllisistä lähes 45 prosenttia ja työllisistä palkansaajista yli 47 prosenttia oli suorittanut vähintään ylemmän keskiasteen tutkinnon.

Työllisten kohonneesta koulutustasosta huolimatta normaalityösuhteet ovat osin alkaneet korvautua määräaikaisilla ja ei-pysyvillä työsuhteilla. Työsuhteiden määräaikaisuus koskee enimmäkseen uusia ja työmarkkinoille siirtyvien nuorten työsuhteita, mutta myös työurallaan edenneiden, varsinkin korkeasti koulutettujen naisten työsuhteita (Santamäki-Vuori \& Sauramo 1993; SVT Työmarkkinat 1993: 2, 1995: 3, 2000: 14; Lehto \& Sutela 1999; Sutela ym. 2001). Vain työllisistä palkansaajista laskettuna normaalityösuhteessa toimivien osuus on pysynyt 80 prosentin tun- 
Taulukko 1. Työllisyyden kehitys koulutusasteen mukaan vuosina 1988!1997.

\begin{tabular}{|c|c|c|c|c|c|}
\hline & $\begin{array}{l}\text { Ei peruskoulun } \\
\text { jälkeistä koulutusta }\end{array}$ & $\begin{array}{l}\text { Alempi } \\
\text { keskiaste }\end{array}$ & $\begin{array}{l}\text { Ylempi } \\
\text { keskiaste }\end{array}$ & Korkea-aste & Yhteensä \\
\hline $\begin{array}{l}\text { Työllisten palkan- } \\
\text { saajien määrä } \\
\text { vuonna } 1988 \\
\text { Keski-ikä }\end{array}$ & $\begin{array}{l}640080 \\
33,9 \% \\
42,6\end{array}$ & $\begin{array}{l}601640 \\
31,8 \% \\
35,4\end{array}$ & $\begin{array}{l}373820 \\
19,8 \% \\
33,8\end{array}$ & $\begin{array}{l}274020 \\
14,5 \% \\
39,4\end{array}$ & $\begin{array}{l}1889560 \\
100 \% \\
38,1\end{array}$ \\
\hline $\begin{array}{l}\text { Työllisyyden } \\
\text { muutos, \% } \\
1988-1990 \\
1991-1993 \\
1994-1997 \\
1988-1997\end{array}$ & $\begin{array}{l}-6,1 \\
-21,9 \\
-7,6 \\
-41,5\end{array}$ & $\begin{array}{l}1,0 \\
-14,5 \\
5,7 \\
-14,2\end{array}$ & $\begin{array}{l}5,1 \\
-9,9 \\
17,0 \\
9,1\end{array}$ & $\begin{array}{l}8,2 \\
0,7 \\
21,0 \\
42,5\end{array}$ & $\begin{array}{l}0,4 \\
-13,1 \\
7,9 \\
-10,6\end{array}$ \\
\hline $\begin{array}{l}\text { Työllisten } \\
\text { palkansaajien } \\
\text { määrä vuonna } \\
1997\end{array}$ & $\begin{array}{l}374580 \\
22,2 \%\end{array}$ & $\begin{array}{l}516060 \\
30,6 \%\end{array}$ & $\begin{array}{l}408020 \\
24,2 \%\end{array}$ & $23,1 \%$ & $\begin{array}{l}1689220 \\
100 \%\end{array}$ \\
\hline Keski-ikä & 44,7 & 40,2 & 36,5 & 39,7 & 40,2 \\
\hline
\end{tabular}

KUVIO 2. Työsuhten normaalisuusaste* koulutusasteen mukaan vuosina 1990-1998. * Normaalityösuhteessa (12 työsuhdekuukautta vuoden aikana) toimineiden osuus palkkatyövoimasta.

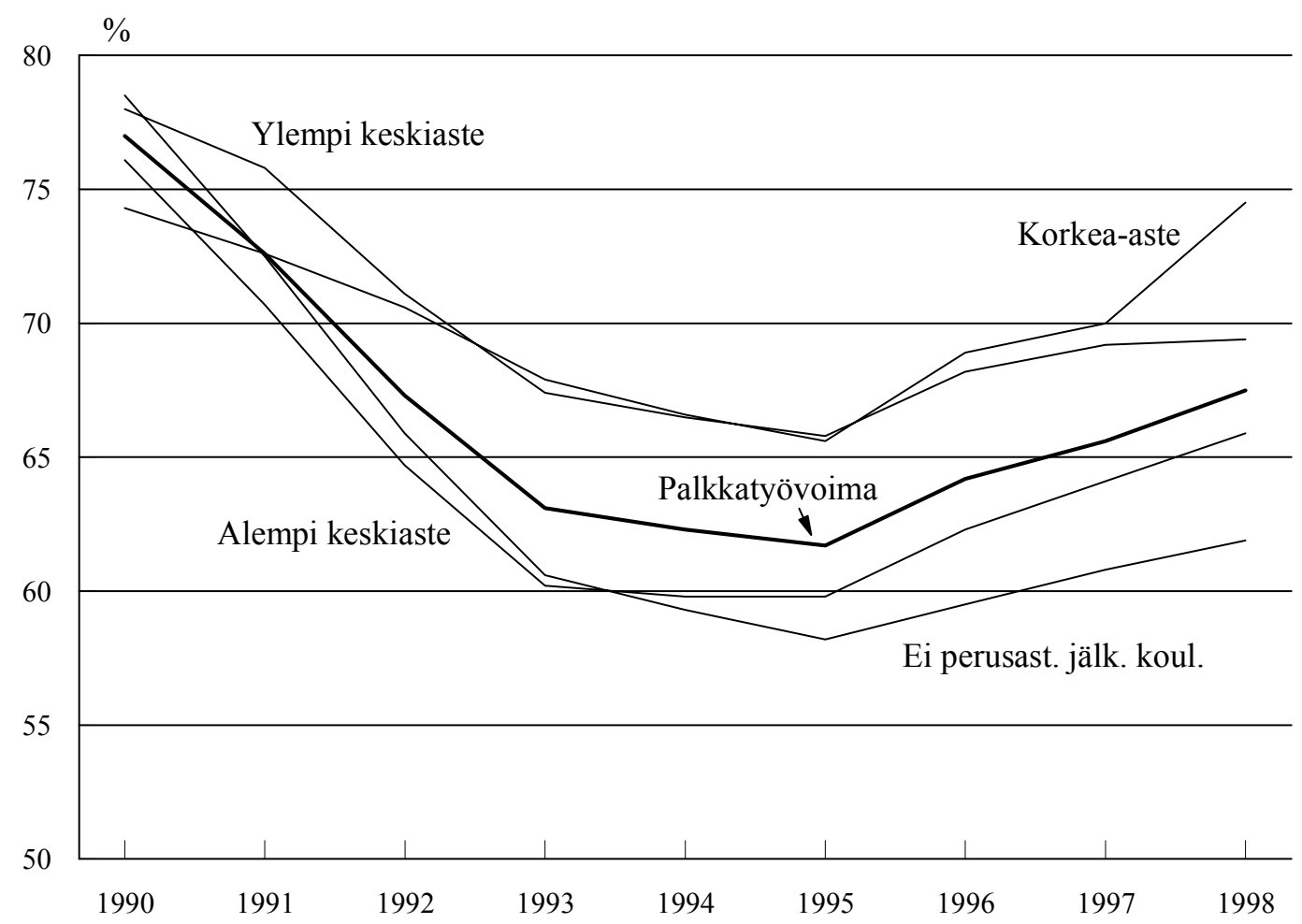


tumassa (ks. Julkunen \& Nätti 1998). Tämä joukko muodostaa palkansaajien ytimen, mutta esimerkiksi vuonna 1998 se tarkoitti itse asiassa vajaata 61 prosenttia koko työvoimasta ja runsasta 67 prosenttia palkkatyövoimasta. Ero 1980luvun lopun tilanteeseen on merkittävä, sillä vuonna 1988 vielä runsas 77 prosenttia palkkatyövoimaan kuuluvista toimi kokovuotisessa palkkatyössä. (Suikkanen 2001, 89.) 1990-luku merkitsi työmarkkinoilla pysyviin työsuhteisiin perustuvan työllisyyden vahvistumisen sijaan vajaatyöllisyyden yleistymistä 1980-lukuun verrattuna.

Kokovuotisessa palkkatyössä toimivien osuus laski 1990-luvulla kaikilla koulutusasteilla, mutta lasku oli rajuinta alemman keskiasteen suorittaneilla ja vailla perusasteen jälkeistä tutkintoa olevilla. Alemman keskiasteen suorittaneilla kokovuotisessa palkkatyössä olevien osuus laski yli 16 prosenttiyksikköä ja vailla perusasteen jälkeistä tutkintoa olevilla jopa yli 20 prosenttiyksikköä vuosina 1990-1995 (kuvio 2).
Alimmillaan vailla perusasteen jälkeistä tutkintoa olevien työsuhteen normaalisuusaste oli 1990-luvulla 58 prosenttia ja alemman keskiasteen tutkinnon suorittaneiden 60 prosenttia. Vuosikymmenen puolivälissä taloudellisen kasvun vuodet voimistivat eriytymiskehitystä. Kun ero vailla perusasteen jälkeistä tutkintoa olevien ja korkea-asteen suorittaneiden osuuksissa oli runsas 7 prosenttiyksikköä vuonna 1995, oli ero vuoteen 1998 mennessä kasvanut jo liki 13 prosenttiyksikköön. Laman jälkeen ainoastaan korkea-asteen tutkinnon suorittaneilla kokovuotisessa palkkatyössä toimivien osuus saavutti lamaa edeltäneen tason. Heidän lisäkseen ylemmän keskiasteen suorittaneet pärjäsivät työmarkkinoilla keskimääräistä paremmin, vaikkakin työsuhteen normaalisuusaste jäi heilläkin 1990-luvun lopussa liki 9 prosenttiyksikköä alemmalle tasolle kuin ennen lamaa.

1990-luvulla työllisen työvoiman rakenne uusiutui voimakkaasti. Työlliseen työvoimaan siirtyi uuden nousukauden vuosina erityisesti vä-

KUVIO 3. Vuosityöttömyysaste* koulutusasteen mukaan vuosina 1990-98. * Vuoden aikana työttömänä olleiden osuus työvoimasta.

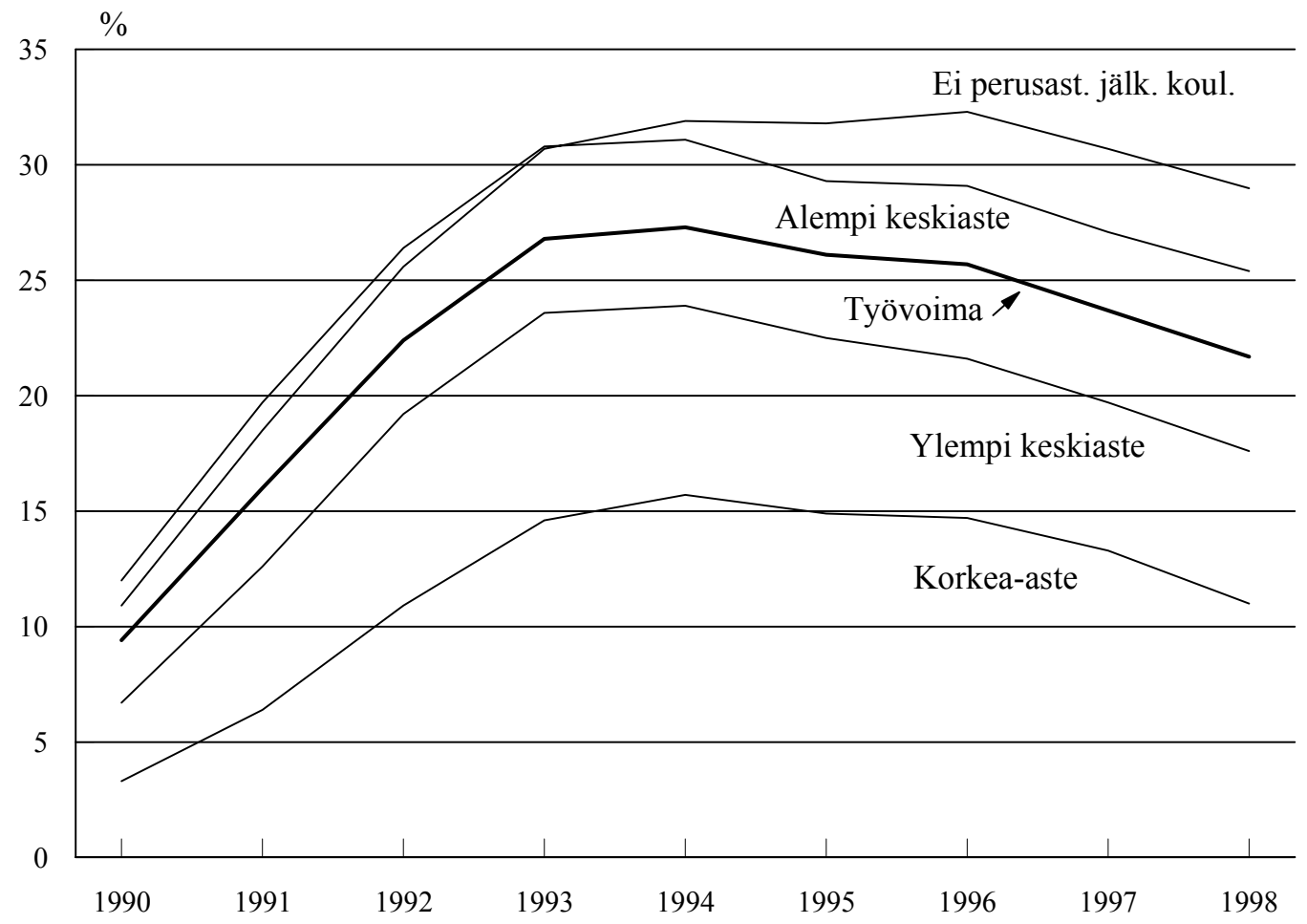


KUVIO 4. Huomattavaa epävarmuutta * työmarkkinoilla kokeneiden osuus työvoimasta koulutus $\%$ asteen mukaan vuosina 1990-98. * 6-11 kuukautta kestänyt työttömyys vuoden aikana.

16

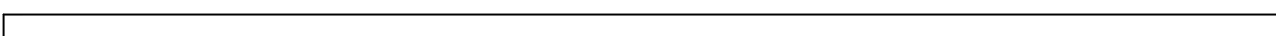

12

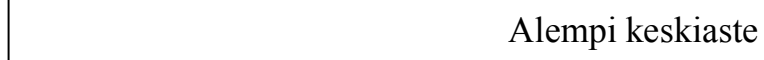

8
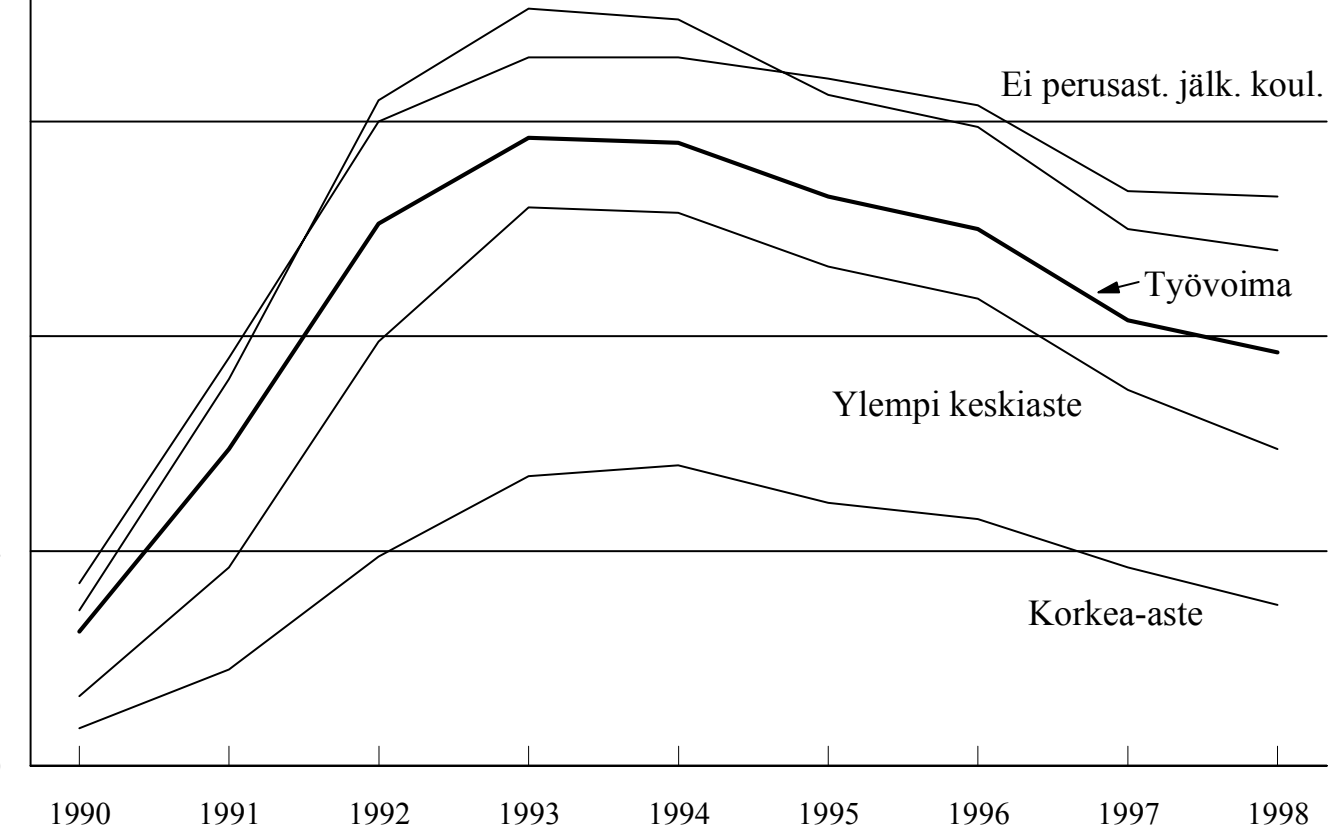

hintään ylemmän keskiasteen tutkinnon suorittaneita. Työllisestä työvoimasta poistuneista puolestaan suurimmalla osalla on ollut huomattavasti tätä alhaisempi koulutus. (Vrt. Kiander ym. 2000, 62-63.) Vähintään ylemmän keskiasteen tutkinto auttoi yksilöitä säilyttämään työmarkkina-asemansa. Se pienensi työttömyysriskiä ja antoi paremmat lähtökohdat sopeutua työmarkkinoiden vaatimuksiin (kuvio 3).

Työttömyysriski on sitä suurempi, mitä alhaisempi koulutustaso on. Vähintään ylemmän keskiasteen suorittaneesta työvoimasta noin 82 prosenttia välttyi työttömyydeltä kokonaan vuonna 1998. Alemman keskiasteen tutkinnon suorittaneista työttömyydeltä välttyi vastaavasti 75 prosenttia ja vailla perusasteen jälkeistä tutkintoa olleista noin 70 prosenttia. Tilapäisen henkilöstön käyttö on niin Suomessa kuin muissakin EUmaissa (European Comission 1997; Tregaskis 1997; Työolobarometrit, lokakuu 1993-1999) lisännyt yksilöiden työttömyyskokemuksia. Vuodesta 1992 lähtien vähintään joka viidennellä suomalaiseen työvoimaan kuuluvalla on ollut vuoden aikana työttömyyskokemuksia. Vailla perusasteen jälkeistä tutkintoa olevilla vastaava osuus on liki kolmasosa ja alemman keskiasteen suorittaneilla lähes saman verran. Työttömyys on lisääntynyt kaikilla koulutusasteilla, mutta erityisesti vähän koulutusta hankkineet ovat joutuneet kohtaamaan epävakaan työllisyyden.

Koulutustaso eriyttää sitä enemmän, mitä pidempään jatkuneesta työttömyydestä on kyse. Koko työvoimassa 6-11 kuukautta vuoden aikana työttömänä olleiden osuus lähes nelinkertaistui (noin kolmesta prosentista liki 12 prosenttiin) vuodesta 1990 vuoteen 1994 (kuvio 4). Alemman keskiasteen suorittaneista lähes 14 prosenttia oli työttömänä 6-11 kuukautta vuonna 1993 ja ylemmän keskiasteen suorittaneistakin useampi kuin joka kymmenes. Korkea-asteen tutkinto suojasi työllisyyden huomattavalta epävarmuudelta suhteellisen hyvin ja selvästi paremmin kuin ylemmän keskiasteen tutkinto. 
KUVIO 5. Vähintään vuoden yhtäkjaksoisesti työttömänä olleiden osuus työvoimasta koulutus asteen mukaan vuosina 1990-98.

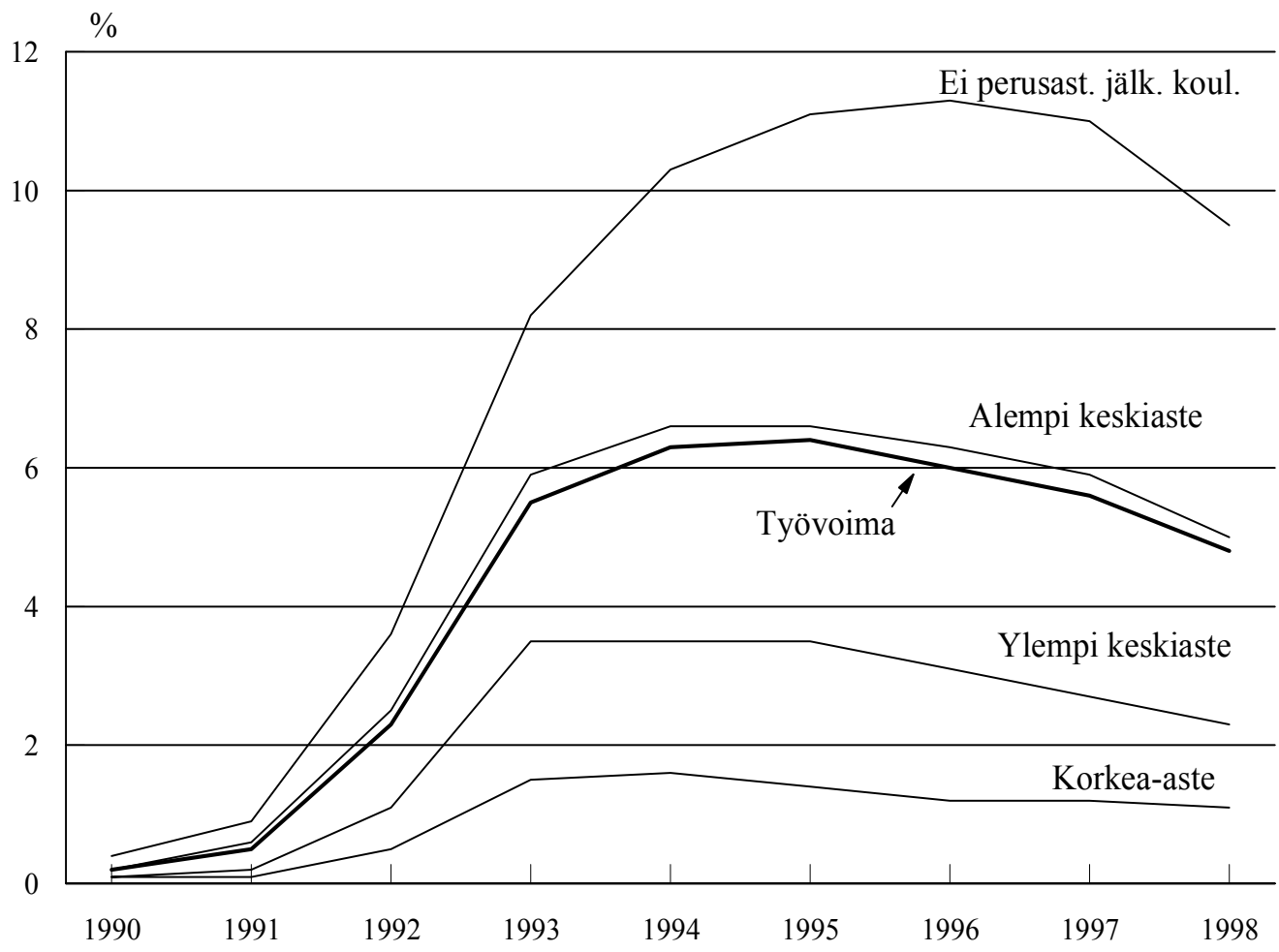

Kun työttömyys on kestänyt yhtäjaksoisesti vähintään vuoden, voidaan jo puhua pitkittyneestä työttömyydestä. Vuosikymmenen alussa koko vuoden kestävä työttömyys oli vielä harvinaista eli alle prosentin luokkaa koulutusasteesta riippumatta. Erityisesti uuden taloudellisen nousun alusta eli vuodesta 1994 lähtien koulutustason merkitys pitkittyneeseen työttömyyteen valikoijana on korostunut. Vailla perusasteen jälkeistä tutkintoa olevat ovat selvästi alkaneet erottua tutkinnon suorittaneista. Useampi kuin joka kymmenes vailla perusasteen jälkeistä tutkintoa olevista työvoimaan kuuluvista oli pitkäaikaistyötön 1990-luvun lopussa. Vuonna 1998 alemman keskiasteen suorittaneissa pitkäaikaistyöttömiä oli lähes saman verran kuin työvoimassa keskimäärin eli noin 5 prosenttia. Ylemmän keskiasteen tai korkea-asteen tutkinnon suorittaneista pitkäaikaistyöttömien osuus jää verraten alhaiseksi, noin 1-2 prosenttiin. (Kuvio 5.)

Työpaikan menettäneiden, vailla perusasteen jälkeistä tutkintoa olevien on vaikea päästä takai- sin työelämään ja heidän työttömyytensä pitkittyy helposti. Työnantajat investoivat nuoriin ja koulutettuihin työntekijöihin. Koulutetun ja nuoren työvoiman kysyntä on kasvanut.

\section{JOHTOPÄÄTÖKSET JA POHDINTA}

Suhteellisen laajasta ja heikosti koulutettujen työttömyydestä näyttää muotoutuneen pysyvä ilmiö. Rakenteellinen ja sitkeä työttömyys on horjuttanut vakavasti työyhteiskunnan ja siihen nojaavan hyvinvointiyhteiskunnan perusteita. Työmarkkinoilla ja taloudessa eivät enää toimi samat säännönmukaisuudet kuin ennen.

Työmarkkinoilla tapahtunut voimakas eriytymis-, valikoitumis- ja yksilöllistymiskehitys asettavat koulutuspolitiikalle, ja yhteiskuntapolitiikalle yleisemminkin, suuria haasteita. Kansallinen kilpailukyky ja yksilöiden selviytyminen työmarkkinoilla tulevat jatkossa riippumaan pitkälle siitä, kuinka hyvin kansalaiset sisäistävät elinikäisen oppimisen idean ja tiedostavat jatkuvan kou- 
lutuksen ja korkean koulutustason merkityksen, sekä siitä, missä määrin ja mille ryhmille jatkuvan kouluttautumisen mahdollisuuksia avataan. Koulutuksen merkityksen korostuessa on tärkeää, että jokaiselle taataan jatkuvan oppimisen perusedellytys eli koulutettavuus. Käytännössä tämä merkitsee mm. tarpeeksi korkean pohjakoulutuksen ja uudenlaisissa oppimisympäristöissä tarvittavien tietoteknisten perusvalmiuksien saannin turvaamista.

Nykytilanteessa erityisesti työmarkkinoilta syrjäytymisvaarassa olevien työllistyvyyden ja koulutettavuuden edistäminen vaatii entistä enemmän panostusta sekä yhteiskuntapoliittista keskustelua. Yksilön työttömyyteen ja sen syihin olisi puututtava heti työttömäksi joutumisen yhteydessä. Erityisesti tulisi pohtia pitkään työttömänä olleiden koulutuksen järjestämisen ja heille tarjottavan koulutuksen (työvoimapoliittisen kurssien) mielekkyyttä suhteessa työmarkkinoiden ja työelämän vaatimuksiin. Työvoimakoulutus toimi aikaisemmin varastona, jossa hankitulle koulutukselle oli käyttöä taloudellisen laskusuhdanteen jälkeen. Tänä päivänä on toisin. Opiskelusta tulisi luoda vaihtoehto työttömyydelle tukemalla työttömien omaehtoiseen, tutkintoon johtavaan koulutukseen hakeutumista. Jälkimodernin koulutuspolitiikan perustuessa markkina-työelämälähtöiseen malliin on vaarana, että osa kansalaisista suljetaan ulos oikeudesta aikuiskoulutukseen tai he pääsevät osallisiksi vain lyhytkestoisesta koulutuksesta. Yksilötasolla lienee kuitenkin niin, että aikuiskoulutukseen osallistumisen keskeinen motiivi ja tavoite on työmarkkinakelpoisuuden ja työllistyvyyden parantaminen. Työttömien aikuisten kanssa voitaisiin laatia räätälöidyt henkilökohtaiset opetussuunnitelmat. Koulutukseen hakeutuneet aikuiset sitoutuisivat suunnitelmaan vastineeksi yhteiskunnan tukemasta koulutuksesta. Aikuisten koulutukseen tulisi myös sisällyttää työnhakutaidot ja osaamisen markkinointi.

Eri yhteiskuntapolitiikan lohkojen yhteistyön lähtökohdaksi voitaisiin ottaa yksilöiden selviytymisen edistäminen ja eriytymiskehityksen pysäyttäminen. Tarvittaisiin sellaisia yhteiskuntapoliittisia reformeja, jotka ottaisivat huomioon uuden toimintaympäristön ja epävakaan työllisyyden. Koulutus-, työllisyys- ja sosiaalipolitiikassa painopistettä tulisi siirtää korjaavasta politiikasta ehkäisevään politiikkaan. Käytännössä tämä merkitsee yksilöiden selviytymisen edistämistä tukemalla koulutukseen hakeutumista työttömyyden sijaan, vähintään ylemmän keskiasteen tutkinnon suorittamisen tukemista ja siihen kannustamista alempien tutkintojen sijaan, koulutuksellisen uusiutumisen suosimista koko työuran ajan edistämällä kaikkien työvoimaan kuuluvien aikuiskoulutusta, erityisen huomion kiinnittämistä työttömyysuhan alaisten koulutukseen sekä nuorten perusasteen jälkeiseen koulutukseen ohjaamista. Elinikäisen oppimisen edistämisessä koko työvoiman osalta oman kysymyksensä muodostaa työn, opiskelun ja perheen arjen yhteensovittaminen. Elinikäiselle opiskelulle tulisi luoda taloudelliset edellytykset niin työelämässä mukana oleville kuin työttömillekin.

Koko työuran aikaista koulutuksellista uusiutumista (alan vaihtoa, uuden tutkinnon suorittamista, ammattiin ja työhön liittyvää koulutusta) voitaisiin tukea esimerkiksi luomalla lisää edellytyksiä työn ohessa tapahtuvaan koulutukseen sekä takaamalla mahdollisuus siirtyä väliaikaisesti työelämästä koulutukseen ja koulutuksesta takaisin työelämään. Näin työvoiman koulutustasoa ja osaamista voitaisiin nostaa aste asteelta. On kuitenkin huomattava, että työttömyysongelma ei ratkea väestön koulutustasoa nostamalla. Työmarkkinoilla tarvitaan uusien yritysten ja työpaikkojen luomista kasvualoille ja rakennemuutoksen kohteena olevien työpaikkojen korvaamista uusilla työpaikoilla.

Elinikäisestä koulutuksesta on puhuttu välttämättömyytenä. Sen sijaan siitä, kenelle kuuluu rahoitusvastuu, on keskusteltu huomattavasti vähemmän. Rahoitusvastuun jakaminen eri toimijoiden välillä vaikuttanee tulevaisuudessa merkittävällä tavalla siihen, kenelle loppujen lopulta avautuu mahdollisuus osallistua koulutukseen. Esimerkiksi opintotukijärjestelmän tulisi tukea nykyistä paremmin elinikäistä oppimista. Työnantajien sosiaalinen vastuullisuus puolestaan tarkoittaisi vastuuta henkilöstön valmentamisesta ja kouluttamisesta yleisesti, eikä vain työpaikan työtehtävien hoitamisessa. 


\section{Lähteet}

BECK, Ulrich (1990). Riskiyhteiskunnan vastamyrkyt. Organisoitu vastuuttomuus. Vastapaino. Tampere.

BECK, Ulrich (1995). Politiikan uudelleen keksiminen: kohti refleksiivisen modernisaation teoriaa. Teoksessa Beck, Ulrich \& Giddens, Anthony \& Lash, Scott 1995: Nykyajan jäljillä. Vastapaino. Tampere, 11-82.

BECK, Ulrich (1999). Työyhteiskunnan tuolle puolen. Janus 3(7), 257-266.

BECK, Ulrich (2000). The Brave New World of Work. Polity Press. ambridge.

European Commission (1997). Employment in Europe. Office for Offical Publications of the European Communities. Luxembourg.

Future Work. Trends and Challenges for Work in the 21 st Century. (2000) Occupational Outlook Quarterly 2 (44), 31-36.

GIDDENS, Anthony (1990). The Consequences of Modernity. Polity Press. Cambridge.

GIDDENS, Anthony (1995). Elämää jälkiteollisessa yhteiskunnassa. Teoksessa Beck, Ulrich \& Giddens, Anthony \& Lash, Scott: Nykyajan jäljillä. Vastapaino. Tampere, 83!152.

HEISKALA, Risto (1998). Modernisoituminen eilen ja tänään. Teoksessa Saksala, Elina (toim.): Muиtoksen sosiologia. Gummerus. Jyväskylä, 165-177.

ILMAKUNNAS, Seija \& Kiander, Jaakko \& Parkkinen, Pekka \& Romppainen, Antti (2000). Globalisaatio ja työn loppu? Talous ja työllisyys vuoteen 2030. VATT-keskustelualoitteita 231. Valtion taloudellinen tutkimuskeskus. Helsinki.

JULKUNEN, Raija \& Nätti, Jouko (1998). Murenee, ei murene, murenee. Janus 3(6), 337-347.

KIANDER, Jaakko \& Kröger, Outi \& Romppanen, Antti (toim. 2000). Talouden rakenteet 2000. Valtion taloudellinen tutkimuskeskus. Yliopistopaino Oy. Helsinki.

KOISTINEN, Pertti (1986). Tuotannollinen rationaliteetti ja sosiaalipoliittisen järjestelmän tulevaisuus. Teoksessa Sosiaalipolitiikka 1986. Sosiaalipoliittinen yhdistys. Vammala, 53-66.

LEHTO, Anna-Maija \& Sutela, Hanna (1999). Tasaarvo työoloissa. SVT Työmarkkinat 1999: 19. Tilastokeskus. Helsinki.

LINNAKANGAS, Ritva (1997). Työpaikan menetys. Tutkimus työsuhteen jatkumisen ja loppumisen sosiaalisista ehdoista. Acta Universitatis Lapponiensis 15. Lapin yliopisto. Lapin Yliopistopaino. Rovaniemi.

PARJANNE, Marja-Liisa (1997). Työmarkkinat murroksessa. Sarja B 135. Elinkeinoelämän tutkimuslaitos ETLA. Taloustieto Oy. Tummavuoren kirjapaino Oy. Vantaa.

SANTAMÄKI-VUORI, Tuire \& Sauramo, Pekka (1993). Lama ja nuorisotyöttömyys. Työpoliittisia tutkimuksia 45. Työministeriö. Helsinki.

SCHMID, Günther (1998). Transitional Labour Markets: A New European Employment Strategy. October 1998. Discussion Paper FS 1, 98-206.

SILVENNOINEN, Heikki (1999). Aikuiskoulutus ja työttömyys. SVT Koulutus 1999: 3. Tilastokeskus. Helsinki.

SUIKKANEN, Asko \& Linnakangas, Ritva \& Kallinen,
Sannamari \& KARJALAINEN, Anne (1998). Palkkatyömarkkinat. Julkaisuja 9. Sosiaali- ja terveysministeriö. Helsinki.

SUIKKANEN, Asko \& Linnakangas, Ritva \& Karjalainen, Anne (1999). 1960-luvulla syntyneiden työmarkkinoille siirtyminen ja työmarkkinakansalaisuus. Teoksessa Linnakangas, Ritva (toim.): Koulutus ja elämänkulku. Näkökulmia koulutuksen vaikuttavuuteen. Yhteiskuntatieteellisiä julkaisuja 28. Lapin yliopisto. Lapin Yliopistopaino. Rovaniemi, 89!226.

SUIKKANEN, Asko \& Linnakangas, Ritva \& Martti, Sirpa \& Karjalainen, Anne (2001). Siirtymien palkkatyö. Raportteja 16. Sitra. Hakapaino. Helsinki.

SUIKKANEN, Asko \& Linnakangas, Ritva \& Martti, Sirpa \& Karjalainen, Anne (2002). Koulutus ja työmarkkinat murroksen yhteiskunnassa. Tutkimushankkeen julkaisematon loppuraportti opetusministeriölle.

SUTELA, Hanna \& Vänskä, Jukka \& Notkola, Veijo (2001). Pätkätyöt Suomessa 1990-luvulla. SVT Työmarkkinat 2001: 1. Tilastokeskus. Helsinki.

SVT Työmarkkinat 1993: 2. Työllisyys, työttömyys ja työolot. Työvoiman vuosihaastattelu, syksy 1991. Tilastokeskus. Helsinki.

SVT Työmarkkinat 1995: 2. Työelämän muutoksia laman aikana. Työvoiman vuosihaastattelu, syksy 1993. Tilastokeskus. Helsinki.

SVT Työmarkkinat 2000: 14. Työvoimatilasto. Tilastokeskus. Helsinki.

Tietoyhteiskunta-asiain neuvottelukunta. Pöytäkirja 7.2.2001. Valtiovarainministeriö.

TREGASKIS, Olga (1997). The 'Non-Permanent' reality! Employee Relations 6 (19), 535-554.

TT:n koulutuspoliittiset teesit 2000. Teollisuuden ja Työnantajain Keskusliitto.

Työolobarometrit, lokakuu 1993-1999. Työministeriö. Helsinki.

VÄHÄTALO, Kari (1998). Työttömyys ja suomalainen yhteiskunta. Gaudeamus. Tammer-Paino. Tampere.

World Employment Report (2001). Life at Work in the Transformation Economy. ILO. Geneva.

Artikkeli saapui toimitukseen 7.1.2002. Se hyväksyttiin julkaistavaksi toimituskunnan kokouksessa 11.3.2002. 